\title{
PENYELENGGARA JALAN SEBAGAI SUBYEK HUKUM TINDAK PIDANA
}

\author{
Oleh: \\ Dewa Arya Lanang Raharja ${ }^{1}$
}

Abstract

As part of the national transportation system, the Traffic and Road Transport should be developed to realize the potential and role, security, prosperity, order traffic and road transportation in order to support economic development and the development of science and technology, regional autonomy, and accountability of state. This research with the normative methods research type, which aims to know and understand who is degan organizers roads and also to know and understand how accountability organizers of the street as legal subjects.

\section{Key Word: Criminal, Traffic and Road Transport}

\begin{abstract}
Abstrak
Sistem transportasi nasional bangsa Indonesia merupakan system transportasi yang lambat kemajuannya, Transportasi Lalu Lintas dan Jalan semestinya dapat dikembangkan guna mewujudkan peran, keamanan, kemakmuran, ketertiban lalu lintas dan angkutan jalan, hal ini berperan di dalam mendukung pembangunan ekonomi dan pengembangan ilmu pengetahuan serta teknologi, otonomi daerah. Penelitian penyelenggara jalan sebagai subjek hukum pidana menggunakan metode penelitian hukum normatif, tujuannya untuk mengetahui dan memahami siapa yang dimaksud degan penyelenggara jalan dan juga untuk mengetahui dan memahami bagaimana pertanggung jawaban penyelenggara jalan sebagai subjek hukum.
\end{abstract}

Kata kunci: Pidana, Lalu Lintas dan Angkutan Jalan

\section{PENDAHULUAN}

Lalu Lintas dan Angkutan Jalan mempunyai peran strategis dalam mendukung pembangunan dan integrasi nasional sebagai bagian dari upaya memajukan kesejahteraan masyarakat seperti amanat UndangUndang Dasar Negara Republik Indonesia Tahun 1945.
Lalu Lintas dan Angkutan Jalan (LLAJ) harus berkembang untuk dapat mewujudkan, kesejahteraan, keamanan, ketertiban dalam lalu lintas dan angkutan jalan dalam rangka mendukung pembangunan ekonomi dan pengembangan ilmu pengetahuan dan teknologi, kemampuan

1 Kejaksaan Negeri Denpasar, Bali. Email : dewdicted@gmail.com 
kemandirian daerah, serta akuntabilitas penyelenggaraan negara ${ }^{2}$.

Pembinaan di bidang lalu lintas dan angkutan jalan di jalankan oleh banyak pihak secara bersama-sama antar instansi terkait (stakeholders) yakni:

1. bagian negara/pemerintah dalam prasaranajalan, olehkementerian atau lembaga yang bertanggung jawab di bidang jalan;

2. bagian negara/pemerintah dalam hal prasarana lalu lintas dan angkutan jalan, oleh kementerian yang bertanggung jawab dalam bagian sarana dan prasarana lalu lintas dan angkutan jalan;

3. bagian negara/pemerintah di bidang pengembangan industri Lalu Lintas dan Angkutan Jalan, oleh kementerian yang bertanggung jawab di bidang industri;

4. bagian negara/pemerintah dalam hal perkembangan teknologi lalu lintas dan angkutan jalan, oleh kementerian yang bertanggung jawab pada bagian teknologi; serta

5. bagian negara/pemerintah dalam hal registrasi dan identifikasi kendaraan bermotor dan

2 Putu Yuni Riswanty, 2013, Batas Kewenangan Penyidik Pegawai Negeri Sipil Dan Kepolisian Dalam Penindakan Pelanggaran Lalu Lintas Dan Angkutan Jalan, Jurnal Magister Hukum Udayana, No. 1, Vol. 2, Edisi Juli 2013,http://ojs. unud.ac.id/index.php/jmhu/article/ view/4443, diakses tanggal 1 Maret 2017. pengendara, aparatur penegak hukum, operasional manajemen dan rekayasa lalu lintas, dan juga pendidikan berlalu lintas oleh pihak Kepolisian.

Kewenangan tersebut dibagi agar setiap pihak yang terlibat dalam penyelenggaraan lalu lintas dapat terlihat lebih jelas dan transparan dengan demikian penyelenggaraan lalu lintas dan angkutan jalan dapat dilaksanakan dengan aman, selamat, lancar, tertib, dan efisien, serta dapat dipertanggungjawabkan. Terhadap bidang yang sifatnya teknis operasional, yang tercantum dalam Undang-Undang Nomor 14 Tahun 1992 tentang Lalu Lintas dan Angkutan Jalan (LLAJ) diatur dalam peraturan pemerintah lengkap dengan peraturan pelaksanaannya, dalam undang-undang tersebut juga mengatur secara tegas dan rinci yang bertujuan agar ada kepastian hukum sehingga tidak lagi diperlukan adanya banyak peraturan pemerintah serta peraturan pelaksanaannya.

Dengan adanya kebijakan yang lebih tajam terkait dengan tujuan serta asas yang termuat di dalam undangundang lalu lintas dan angkutan jalan, maka akan dapat tercipta lalu lintas dan angkutan jalan yang tertib, lancar, selamat, aman, juga terintegrasi dengan moda transportasi lainnya, tujuannya tidak lain agar perekonomian nasional dapat berkembang, sehingga kesejahteraan rakyat dapat terwujud, persatuan dan kesatuan bangsa dapat 
terpelihara. Keamanan merupakan salah satu element yang sangat diperhatikan dalam pengaturan undang-undang angkutan jalan dan lalu lintas. Selain itu, undang-undang angkutan jalan dan lalu lintas juga dapat mewujudkan perilaku dalam berlalu lintas serta budaya bangsa (just culture) melalui usaha pembinaan, pemberian bimbingan, dan pendidikan lalu-lintas sejak kecil atau usia dini dengan program yang berkelanjutan.

Mengantisipasi perkembangan global yang membutuhkan persaingan yang tinggi, maka diperlukan berbagai terobosan yang bersifat progresif, maka semangat dalam undang-undang ini memunculkan adanya penyelenggaraan lalu lintas yang sifatnya lintas sectorial, yang terkoordinasi dengan para pemangku kepentingan dalam penyelenggaraan lalu lintas dan angkutan jalan, sehingga dalam undang-undang ini diamanatkan terbentuknya forum lalu lintas dan angkutan jalan.

Forum lalu lintas dan angkutan jalan merupakan lembaga ad hoc, badan ini berperan penting dalam menyinergikan tugas pokok dan fungsi dari seluruh instansi terkait dalam hal mengatasi dan menganalisis serta memberikan solusi dalam setiap permasalahan yang terjadi selama penyelenggaraan kegiatan lalu lintas dan angkutan jalan.

Forum lalu lintas dan angkutan jalan juga berperan penting dalam penyelenggaraan koordinasi antar instansi sehingga terjadi keterpaduan dalam penyelesaian masalah lalu lintas. Selanjutnya agar dapat mempertahankan jalan yang layak atau kondisi jalan yang baik guna mengatasi tingginya angka kecelakaan akibat jalan yang rusak, dalam undangundang ini juga telah dimunculkan adanya dana preservasi jalan. Dana preservasi jalan pemanfaatannya dikhususkan pada konstruksi jalan, pemeliharaan serta rehabilitasi jalan yang dikelola atas dasar prinsip akuntabilitas, transparansi, seimbang dan sesuai. Pengelolaan dana preservasi jalan ini dilakukan dalam unit tersendiri yang bertanggung jawab kepada Menteri yang membidangi jalan, dan pelaksanaannya dilakukan sesuai dengan peraturan perundangundangan.

Angka kecelakaan yang terjadi dijalan raya dengan adanya Forum lalu Lintas dan Angkutan jalan ternyata tidak serta-merta dapat menurunkan angka kecelakaan kendaraan bermotor, dikutip dari Sindo News sebanyak $10 \%$ penyebab kecelakaan di jalan, dikarenakan jalan berlubang atau rusak. Hal itu diungkapkan Wadir (wakil direktur) lalu lintas Polda Metro Jaya AKBP Wahyono. Menurutnya, setiap ada jalan rusak akan difoto dan dikirimkan surat kepada Dinas PU untuk segera memperbaiki Dia menegaskan, dari data yang dimiliki Polda Metro Jaya, kurang lebih 10 \% terjadinya kecelakaan disebabkan oleh jalan yang rusak. 
Pasal 24 ayat (1) undang-undang nomor 22 Tahun 2009 tentang lalu lintas dan angkutan jalan ditentukan, penyelenggara jalan wajib dan patut untuk memperbaiki jalan yang rusak yang dapat mengakibatkan kecelakaan lalu lintas. Penyelenggara jalan yang tidak segera dan patut memperbaiki jalan yang rusak yang mengakibatkan kecelakaan lalu lintas sehingga menimbulkan korban luka ringan dan/atau kerusakan kendaraan dan/ atau barang dipidana dengan penjara paling lama 6 (enam) bulan atau denda paling banyak Rp. 12.000.000,00 (dua belas juta rupiah) sesuai dengan Pasal 273 ayat (1). Dalam hal perbuatan mengakibatkan luka berat, pelaku dipidana dengan pidana penjara paling lama 1 (satu) tahun atau denda paling banyak Rp. 24.000.000,- (dua puluh empat juta rupiah). Dalam hal perbuatan mengakibatkan orang lain meninggal dunia, pelaku dipidana dengan pidana penjara paling lama 5 (lima) tahun atau denda paling banyak Rp. 120.000.000, - (seratus dua puluh juta rupiah). Ketentuan sebagaimana di atas ternyata tidak memberikan penjelasan siapa sesungguhnya yang dimaksud sebagai penyelenggara jalan.

Berdasarkan ketentuan Pasal 24 ayat (1) dan Pasal 273 ayat (1) UU No. 22 Tahun 2009 Tentang Lalu Lintas Angkutan Jalan bahwa penyelenggara jalan yang tidak segera memperbaiki kerusakannya dapat dikenakan sanksi berupa pidana penjara dan denda.
Sehingga yang menjadi pertanyaan di sini ialah mengenai siapa yang dimaksud dengan penyelenggara jalan dan bagaimana prosedur pidana terhadap penyelenggara jalan dapat diterapkan.

Berdasarkan latar belakang masalah di atas, maka rumusan masalah yang dapat dikemukakan dalam penelitian ini yaitu sebagai berikut:

1. Siapakah yang dimaksud dengan penyelenggara jalan dalam Undang-Undang No 22 Tahun 2009 tentang Lalu-Lintas Angkutan Jalan?

2. Bagaimana pertanggung jawaban pidana penyelenggara jalan sebagai subjek hukum?

Penelitian ini merupakan karya ilmiah asli yang belum pernah diteliti sebelumnya. Adapun karya ilmiahyang terkait dengan karya ilmiah Penulis tentang Penyelenggara Jalan Sebagai Subjek Hukum Tindak Pidana yaitu karya ilmiah dari Dewa Putu Tagel tahun 2013 dengan judul Kesadaran Hukum Masyarakat Pengguna Jalan Di Kota Denpasar yang rumusan masalahnya adalah; 1. Bagaimanakah tingkat kesadaran hukum masyarakat pengguna jalan?; 2. Faktor-faktor apakah yang mempengaruhi kesadaran hukum masyarakat pengguna jalan?; 3 . Usaha-usaha apakah yang dilakukan Kepolisian dalam meningkatkan kesadaran hukum masyarakat pengguna jalan?. Karya ilmiah lainnya yang terkait yaitu Putu Yuni 
Riswanty tahun 2013 dengan judul Batas Kewenangan Penyidik Pegawai Negeri Sipil Dan Kepolisian Dalam Penindakan Pelanggaran Lalu Lintas Dan Angkutan Jalan yang rumusan masalahnya adalah; 1. Apakah Kewenangan Penyidik Pegawai Negeri Sipil bidang Lalu Lintas dan Angkutan Jalan dapat dilakukan oleh Penyidik Kepolisian Republik Indonesia?; 2. Penindakan pelanggaran Lalu Lintas dan Angkutan Jalan di Jalan apakah yang dapat dilakukan oleh Penyidik Pegawai Negeri Sipil bidang Lalu Lintas dan Angkutan Jalan? Jelas nampak perbedaan dari karya ilmiah tersebut dengan karya ilmiah yang dibuat oleh Penulis. Adapun keunggulan karya ilmiah ini dari karya ilmiah lainnya yaitu karya ilmiah ini membahas lebih dalam tentang siapa yang dimaksud degan penyelenggara jalan serta membahas bagaimana pertanggung jawaban penyelenggara jalan sebagai subjek hukum.

Adapan tujuan dari penelitian ini yaitu untuk mengetahui dan memahami siapa yang dimaksud degan penyelenggara jalan dan juga untuk mengetahui dan memahami bagaimana pertanggung jawaban penyelenggara jalan sebagai subjek hukum.

\section{METODE PENELITIAN}

Penelitian ini adalah penelitian hukum normatif, penelitian hukum normative mengkaji asas hukum, sistematika hukum, taraf sinkronisasi vertical dan horizontal, mengkaji perbandingan-perbandingan hukum serta sejarah hukum. ${ }^{3}$ Penelitian hukum normative mendasarkan pada bahan hukum primer dan sekunder.

\section{HASIL PEMBAHASAN \\ 3.1 Penyelenggara Jalanan Sebagai Subjek Hukum Tindak Pidana}

Tindak pidana adalah perbuatan yang dilarang oleh hukum, larangan tersebut disertai dengan (sanksi) berupa pidana tertentu bagi si pelanggar aturan tersebut. Ada 3 (tiga) hal yang perlu diperhatikan:

1. Perbuatan pidana adalah perbuatan oleh suatu aturan hukum dilarang dan diancam pidana.

2. Larangan ditujukan kepada perbuatan (yaitu suatu keadaan atau kejadian yang ditimbulkan oleh kelakuan orang), sedangkan ancaman pidana ditujukan kepada orang yang menimbulkan kejadian itu.

3. Antara larangan dan ancaman pidana ada hubungan yang erat, oleh karena antara kejadian dan orang yang menimbulkan kejadian itu ada hubungan erat pula. "Kejadian tidak dapat dilarang jika yang menimbulkan bukan orang, dan orang tidak dapat diancam pidana jika tidak karena kejadian yang ditimbulkan olehnya".

3 Soerjono S. \& SriM., 2012, Penelitian Hukum Normatif. Suatu tinjauan singkat, Cet. Ke-14, PT. Raja Grafindo, Jakarta, hlm.14 
Berkaitan dengan ketentuan dalam UU No. 22 Tahun 2009 Tentang Lalu Lintas Angkutan Jalan sebagaimana termaktub dalam Pasal 24 ayat (1) menyebutkan Penyelenggara Jalan wajib untuk melakukan perbaikan jalan yang rusak yang dapat menimbulkan kecelakaan lalu lintas.

Istilah penyelenggara jalan telah dimunculkan oleh pembuat undang-udang mengenai kewajiban penyelenggara jalan memperbaiki jalan-jalan yang rusak yang dapat mengakibatkan kecelakaan lalu lintas, dan sebagai upaya paksa untuk memberikan kepatuhan kepada penyelenggara jalan guna melaksanakan kewajibannya untuk memperbaikijalanyangrusakkemudian diatur ketentuan pidana dalam Pasal 273 ayat (1) Setiap penyelenggara Jalan yang tidak dengan segera dan patut memperbaiki Jalan yang rusak yang mengakibatkan Kecelakaan Lalu Lintas sebagaimana dimaksud dalam Pasal 24 ayat (1) sehingga menimbulkan korban luka ringan dan/ atau kerusakan Kendaraan dan/atau barang dipidana dengan penjara paling lama 6 (enam) bulan atau denda paling banyak Rp12.000.000,00 (dua belas juta rupiah)

Peraturan perundang-undangan pidana selalu mengatur tentang tindak pidana, begitu pula dengan tindak pidana yang diatur terhadap penyelenggara jalan. Menurut Moeljatno "Tindak pidana adalah perbuatan yang dilarang oleh suatu aturan hukum, larangan mana disertasi ancaman (sanksi) yang berupa pidana tertentu bagi barang siapa yang melanggar larangan tersebut". Untuk mengetahui adanya tindak pidana, maka pada umumnya dirumuskan dalam peraturan perundang-undangan pidana tentang perbuatan-perbuatan yang dilarang dan disertai dengan sanksi. Dalam rumusan tersebut ditentukan beberapa unsur atau syarat yang menjadi ciri atau sifat khas dari larangan tadi sehingga dengan jelas dapat dibedakan dari perbuatan lain yang tidak dilarang. Perbuatan pidana menunjuk kepada sifat perbuatannya saja, yaitu dapat dilarang dengan ancaman pidana kalau dilanggar.

Menurut Simons, unsur-unsur tindak pidana (strafbaar faith) adalah:

1. Perbuatan manusia (positif atau negatif, berbuat atau tidak berbuat atau membiarkan).

2. Diancam dengan pidana (statbaar gesteld)

3. Melawan hukum (onrechtmatig)

4. Dilakukan dengan kesalahan (met schuld in verband stand)

5. Oleh orang yang mampu bertanggung jawab (toerekeningsvatoaar person)

Simons menjabarkan unsur objektif serta unsur subjektif dari tindak pidana (strafbaar feit) yakni ${ }^{4}$ : Unsur Objektif:

1. Perbuatan orang

2. Akibat yang kelihatan dari perbuatan itu

4 Badan Diklat Kejaksaan Republik Indonesia, Modul Asas-Asas Hukum Pidana, Jakarta, hlm. 20 
3. Mungkin ada keadaan tertentu yang menyertai perbuatan itu seperti dalam Pasal281 KUHP sifat "openbaar" atau "dimuka umum"

Unsur Subjektif:

1. Orang yang mampu bertanggung jawab

2. Adanya kesalahan (dollus atau culpa). Perbuatan harus dilakukan dengan kesalahan. Kesalahan ini dapat berhubungan dengan akibat dari perbuatan atau dengan keadaan mana perbuatan itu dilakukan.

Sedangkan Moeljatno menyebutkan unsur-unsur perbuatan pidana ${ }^{5}$ :

1. Perbuatan (manusia)

2. Yang memenuhi rumusan dalam Undang-Undang (syarat formil)

3. Bersifat melawan hukum (syarat materiil)

Unsur-unsur tindak pidana menurut Moeljatno terdiri dari:

1) Kelakuan dan akibat

2) Hal ikhwal atau keadaan tertentu yang menyertai perbuatan, yang dibagi menjadi :

a. Unsur subjektif atau pribadi

Yaitu mengenai diri orang yang melakukan perbuatan, misalnya unsur pegawai negeri yang diperlukan dalam delik jabatan seperti dalam perkara tindak pidana korupsi. Pasal 418 KUHP jo. Pasall ayat (1) sub c UU
No 3 Tahun 1971 atau Pasal 11 UU No. 31 Tahun 1999 jo UU No. 20 Tahun 2001 tentang pegawai negeri yang menerima hadiah. Kalau yang menerima hadiah bukan pegawai negeri maka tidak mungkin diterapkan Pasal tersebut.

b. Unsur objektif atau non pribadi

Yaitu mengenai keadaan di luar si pembuat, misalnya Pasal 160 KUHP tentang penghasutan di muka umum (supaya melakukan perbuatan pidana atau melakukan kekerasan terhadap penguasa umum). Apabila penghasutan tidak dilakukan di muka umum maka tidak mungkin diterapkan Pasal ini. ${ }^{6}$

Berkaitan dengan unsur-unsur dari tindak pidana yang diatur dalam ketentuan Pasal 273 ayat (1) UU No. 22 Tahun 2009 Tentang Lalu Lintas Angkutan Jalan, maka telah jelas bahwa Penyelenggara Jalan ditempatkan sebagai subjek hukum pidana atas kedudukannya sebagai badan hukum publik.

$6 \quad$ Ibid hlm. 22 


\subsection{Pertanggung Jawaban Hukum Penyelenggara Jalan Sebagai Pelaku Tindak Pidana.}

Berkaitan dengan ajaran mens rea, dalam Pasal 273 UU No. 22 Tahun 2009 Tentang Lalu Lintas Angkutan Jalan tersebut harus dibuktikan terlebih dahulu sikap batin atau kemampuan jiwa dari penyelenggara jalan, apakah penyelenggarajalan tidakmemperbaiki jalan yang rusak karena sengaja atau lalai. Perbedaan antara sengaja dan lalai yakni pada kesengajaan sikap batin seseorang memang melanggar, sedangkan dalam kealpaan sikap batin orang ini hanya tidak mengindahkan larangan hukum sehingga tidak berhatihati dalam melakukan suatu perbuatan yang menimbulkan keadaan yang dilarang. Sebagai bentuk kesalahan dalam hukum pidana, keduanya hanya berbeda secara "gradual" atau secara kualitas saja.

Sebagaimana telah diatur dalam UU No. 22 Tahun 2009 Tentang Lalu Lintas Angkutan Jalan Perbuatan penyelenggara jalan yang tidak segera memperbaiki jalan yang rusak sehingga menyebabkan laka lantas telah dicantumkan sebagai delik pidana dalam UU No. 22 Tahun 2009 Tentang Lalu Lintas Angkutan Jalan. Dan sebagai penyelenggara jalan yang bertanggung jawab atas kelayakan fungsi jalan sepatutnya mengetahui bahwa jalan yang digunakan oleh masyarakat harus memenuhi standar keamanan dan keselamatan berlalu lintas. Olehkarenaitu, penyelenggaraan jalan yang tidak memperbaiki jalan rusak dengan segera dapat dikatakan lalai dalam menjalankan tugasnya menyediakan fasilitas jalan yang layak fungsi atau memenuhi standar keamanan.

Dengan demikian, dalam kasus kecelakaan lalu lintas akibat jalan ang rusak penyelenggara jalan mempunyai kemampuan untuk bertanggung jawab, hal ini karena penyelenggara jalan lalai dalam hal :

1. Tidak memperbaiki jalan yang rusak dengan segera sehingga mengakibatkan laka lantas.

2. Tidak memberikan peringatan pada jalan yang belum diperbaiki.

3. Tidak melakukan perawatan dan perbaikan jalan sehingga masih banyak ditemui kerusakan jalan, baik jalan yang retak, distorsi, cacat permukaan, maupun berlubang.

4. Tidak memenuhi standar keamanan dan keselamatan lalu lintas darat.

Menurut Jimly Asshiddiqie pertanggungjawaban ada dua yakni pertanggung jawaban personal atau pribadi dan pertanggung jawaban institusional atau jabatan. Lebih lanjut dikatakan bahwa seorang pejabat di dalam melaksanakan tugas dan kewenangannya sesuai dengan norma atau peraturan hukum yang berlaku, maka tindakannya tersebut dipertanggungjawabkan secara jabatan (institusional). Tetapi sebaliknya jika seorang pejabat melaksanakan tugas 
dan kewenangannya melanggar norma atau aturan hukum yang berlaku, maka pelaksanaan tindakannya dipertanggungjawabkan secara pribadi atau pertanggungjawaban personal ${ }^{7}$.

Pertanggungjawaban hukum mengandung arti bahwa baik pemerintah maupun pemerintah daerah dalam menyelenggarakan pemerintahan yang merugikan kepentingan rakyat atau pihak lain harus mempertanggungjawabkan dan menerima tuntutan hukum atas perbuatannya tersebut. Pertanggungjawaban hukum oleh pemerintah dapat dilakukan melalui 3 (tiga) sarana, yaitu melaui hukum administrasi, melalui hukum perdata, serta hukum pidana. Berdasarkan instrument hukum tersebut, maka dikenal adanya pertanggungjawaban administrasi, pertanggungjawaban perdata, serta pertanggungjawaban pidana.

Dalam kaitannya dengan pertanggungjawaban hukum, Hadjon mengatakan bahwa tindakan pejabat harus dicermati, apakah tindakan tersebut termasuk tanggung jawab jabatan atau tanggung jawab pribadi. Pada dasarnya setiap pejabat pemerintah dalam melakukan tindakan pemerintahan dibebani tanggung jawab jabatan dan tanggung jawab pribadi. Yang membedakan antara tanggung jawab jabatan dan

7 Jimly Asshiddiqie, Islam dan Tradisi Negara Konstitusi, Makalah pada seminar Indonesia Malaysia, (Uin/IAIN Padang, 2010), hlm. 12 tanggung jawab pribadi atas tindak pemerintahan membawa konsekuensi yang berhubungan dengan tanggung jawab pidana, perdata, dan tanggung jawab administrasi. Mengenai pertanggungjawaban hukum pemerintah / pemerintah daerah dalam penyelenggaraan pemerintah, dapat dilakukan setiap saat tanpa harus menunggu berakhirnya masa jabatannya.

Walaupun telah jelas disebutkan dalam ketentuan Pasal 273 UU No. 22 Tahun 2009 Tentang Lalu Lintas Angkutan Jalan penyelenggara jalan dapat dijatuhi pidana, namun dalam peraturan undang-undang yang sama, sama sekali tidak ditemukan satu ketentuan Pasal maupun satu penjelasan Pasal pun yang dapat memberikan pemahaman siapa yang dimaksud dengan penyelenggara jalan.

Namun kriteria untuk dapat menentukan kapan penyelenggara jalan dapat dijatuhi pidana telah jelas termaktub dalam ketentuan Pasal 273 UU No. 22 Tahun 2009 Tentang Lalu Lintas Angkutan Jalan yakni:

1. penyelenggara jalan yang tidak segera dan patut memperbaiki jalan yang rusak yang mengakibatkan kecelakaan lalu lintas sebagaimana dimaksud dalam Pasal24 ayat (1) sehingga menimbulkan korban luka ringan dan/atau kerusakan kendaraan dan/atau barang dipidana dengan penjara paling lama 6 (enam) 
bulan atau denda paling banyak rp 12.000.000,00 (dua belas juta rupiah).

2. Dalam hal perbuatan sebagaimana dimaksud pada ayat (1) mengakibatkan luka berat, pelaku dipidana dengan pidana penjara paling lama 1 (satu) tahun atau denda paling banyak Rp 24.000.000,00 (dua puluh empat juta rupiah)

3. Dalam hal perbuatan sebagaimana dimaksud pada ayat (1) mengakibatkan orang lain meninggal dunia, pelaku dipidana dengan pidana penjara paling lama 5 (lima) tahun atau denda paling banyak $\mathrm{Rp}$ 120.000.000,00 (seratus dua puluh juta rupiah).

4. Penyelenggara Jalan yang tidak memberi tanda atau rambu pada jalan yang rusak dan belum diperbaiki sebagaimana dimaksud dalam Pasal 24 ayat (2) dipidana dengan pidana penjara 6 (enam) bulan atau denda paling banyak Rp 1.500.000,00 (satu juta lima ratus ribu rupiah).

Berdasarkan uraian Pasal 273 Undang-undang Nomor 22 Tahun 2009 Tentang Lalu Lintas dan Angkutan Jalan tersebut, dapat dilihat bahwa tindak pidana yang diatur dalam Pasal tersebut merupakan tindak pidana materiil. Artinya tindak pidana yang dilarang dalam Pasal 273 tersebut adalah tindak pidana yang menimbulkan akibat kecelakaan.
Dengan demikian tindak pidana materiil adalah tindak pidana yang dirumuskan dengan melarang suatu perbuatan yang dapat menimbulkan akibat atau disebut akibat terlarang. Terjadinya suatu perbuatan tidak bergantung pada selesainya perbuatan tersebut akan tetapi apakah pada wujud perbuatan tersebut telah menimbulkan akibat terjadinya kecelakaan lalu lintas di jalan.

Terwujudnya tindak pidana materiil oleh penyelenggaraan jalan dengan berdasarkan Pasal 273 UU No. 22 Tahun 2009 Tentang Lalu Lintas Angkutan Jalan secara sempurnaadalah apabila ada akibat berupa kecelakaan lalu lintas di jalan yang timbul dari perbuatan penyelenggara jalan yang tidak segera dan patut memperbaiki jalan yang rusak. Untuk menentukan apakah kecelakaan lalu lintas yang terjadi disebabkan oleh perbuatan penyelenggara jalan, maka dapat dilihat dari kronologis kejadian tersebut, apabilaterdapathubungankausal antara perbuatan penyelenggara jalan yang tidak segera dan patut memperbaiki jalan rusak dengan akibat yang ditimbulkan. Dengan demikian dalam menentukan pertanggungjawaban pidana penyelenggaraan jalan dengan memperhatikan Pasal 273 UU No. 22 Tahun 2009 Tentang Lalu Lintas Angkutan Jalan, ajaran kausalitas menjadi sangat penting, karena akan menunjukkan perbuatan mana yang sebenarnya yang harus dianggap sebagai penyebab dari kecelakaan lalu lintas di jalan. 
Untuk dapat lebih jauh menentukan bagaimana bentuk pertanggung jawaban pidana penyelenggara jalan bilamana terjadi kecelakaan lalu lintas yang diakibatkan dari jalan yang rusak maka terlebih dahulu harus diperjelas siapa yang dimaksud dengan penyelenggara jalan, apakah Dinas PU sebagai SKPD yang bertanggungjawab dalam kegiatan proyek pekerjaan Jalan, ataukah Dinas Perhubungan atau instansi lainnya yang terkait dalam UU No. 22 Tahun 2009 Tentang Lalu Lintas Angkutan Jalan, sehingga ketentuan pidana terhadap penyelenggara jalan tidak hanya menjadi sebuah Pasal pajangan dalam UU No. 22 Tahun 2009 Tentang Lalu Lintas Angkutan Jalan.

\section{KESIMPULAN}

Berdasarkan pembahasan diatas, maka dapat disimpulkan sebagai berikut:

1. Tidak ada penjelasan dalam UU No. 22 Tahun 2009 Tentang Lalu Lintas Angkutan Jalan yang dapat menyebutkan siapakah yang dimaksud dengan penyelenggara jalan yang mempunyai kewajiban untuk memperbaiki jalan yang rusak dapat dihindari.

2. Pertanggung jawaban pidana terhadap penyelenggara jalan tidak dapat dilaksanakan karena, penyelenggara jalan sebagai badan hukum publik tidak ditentukan dengan tegas, siapa saja yang berada di dalamnya serta bagaimana susunan lembaganya.

\section{DAFTAR PUSTAKA}

Buku:

Soerjono S. \& SriM, 2012, Penelitian Hukum Normatif Suatu Tinjauan Singkat,, Cet. Ke-14, PT. Raja Grafindo, Jakarta.

Jimly Asshiddiqie, 2010, Islam dan Tradisi Negara Konstitusi, Makalah pada Seminar Indonesia Malaysia, Uin/IAIN, Padang.

Philipus M. Hadjon, 2012, Pemerintahan Menurut Hukum, Universitas Airlangga, Surabaya.

Artikel majalah ilmiah versi online: Putu Yuni Riswanty, 2013, Batas Kewenangan Penyidik Pegawai Negeri Sipil Dan Kepolisian Dalam Penindakan Pelanggaran Lalu Lintas Dan Angkutan Jalan, Jurnal Magister Hukum Udayana, No. 1, Vol. 2, Edisi Juli 2013, <https://ojs.unud. ac.id/index.php/jmhu/article/ view/4443>,diakses tanggal 1 Maret 2017. doi: https://doi. org/10.24843/JMHU.2013.v02. i01.p09.

Badan Diklat Kejaksaan Republik Indonesia, Modul Asas-Asas Hukum Pidana, Jakarta.

\section{Peraturan Perundang-Undangan:}

UU Nomor 22 Tahun 2009 Tentang LLAJ (Lalu Lintas dan Angkutan Jalan). 